\title{
IMMIGRANT CHILDREN EDUCATION AS MEANS OF INTEGRATION: THE LITHUANIAN CASE
}

\author{
MONIKA ORECHOVA \\ Vilnius University, Faculty of Philosophy, Institute of Educational Science \\ Universiteto str. 9/1, Vilnius \\ E-mail address: monika.orechova@fsf.vu.lt
}

\begin{abstract}
Aim. This research paper discusses the educational process of immigrant children in Lithuania with the intention to determine the integration trajectory most likely to be chosen by the immigrant students.

Methods. The research methods include legal analysis of Lithuanian legislations related to immigration, immigrant integration and education, meta-analysis of previous research on immigrant integration into Lithuanian society as well as semi-structured interviews with experts of the field.

Results. Having completed the research, the following conclusion has been drawn: immigrant children's education in Lithuania does not tend to create conditions for successful integration and it influences immigrant students' choice of integration paths that may inspire inner or outer conflict. This is due to the lack of integration policy and strategy at the state level as well as the tendency to create cultural hierarchy within the Lithuanian culture considered as above others.

Practical application. The results of the research can be used to improve the conditions of immigrant children's education in Lithuanian schools on the national level as well as by schools willing to foster the integration of immigrant students; the results can also be considered in the process of establishing integration policy on the state level.

Key words: immigrant education, immigrant integration, integration trajectories.
\end{abstract}

\section{INTRODUCTION}

The transformation of a homogeneous society into a heterogeneous one and the inclusion of culturally diverse members is a complicated and multifaceted process, which occurs in different areas and on different terms. Education, with its social function, undoubtedly, has a significant role in this process. Due to immigrant children spending the majority of their time at educational institutions, such institutions become the primary arena for their integration and the measures they adopt highly influence the process of their integration and its success.

Based on the reports by the Lithuanian Department of Statistics, immigration into Lithuania has been steadily increasing. The number of immigrants during the period from 2010 to 2016 has grown more than three times: from 
1673 to 5955 immigrants per year (not including re-imigrating Lithuanian citizens). The number of immigrating children has also been increasing in recent years, albeit not as drastically; in the school year of 2012-2013 (such data had not been collected previously) there were 1119 schoolchildren holding a nonLithuanian citizenship, while in 2017 there were 1504. However, the Lithuanian experience regarding the integration of immigrant students in the schools of general education so far has been rather scarce and one-dimensional, mostly concerned with a small number of immigrants from the countries of the postSoviet bloc.

Immigration and immigrant integration are both rather new research areas in Lithuania. While there have been several publications regarding these topics (see Bartkevičienè, Raudeliūnaitė, 2012; Platačiūtè, Žibas, 2014), the only research related to the field of education has been conducted in 2005 by a research group led by Vilma Žydžiūnaitè which was commissioned by the Ministry of Education and Science of Lithuania. Their work was aimed at highlighting the conditions created by the system of education to foster full-fledged teaching and learning processes for immigrant students (Žydžiūnaitè, et al., 2005).

Additionally, the results of a public opinion survey commissioned by the Institute of Ethnic Studies of the Lithuanian Social Research Centre in 2014 have shown that immigrant children education is considered the most acceptable means of integration - this was the choice made by more than three quarters of the respondents (Etninių tyrimu institutas, 2015). Therefore, immigrant children education is not only a much needed but also an acceptable instrument of integration. Given this context as well as the slowly increasing number of immigrants, it is of great importance to critically evaluate the status quo in Lithuania, and to try to determine what could be the process of integration of the immigrant children educated in Lithuania, and how the educational system could influence the success of this process. This research, thus, has the following objectives: first, to investigate the legal documents and policy papers that pertain to immigrant education in order to determine what implications they have on immigrant integration; second, to conduct interviews with the experts in the field in order to establish the ways the aforementioned legal and political implications are reflected in actual processes of education and integration.

\section{WHY 'INTEGRATION': METHODOLOGICAL IMPLICATIONS OF THE TERM}

While there are quite a few nuanced terms regarding the process of immigrant inclusion in the host society, the two most prevalent are assimilation and integration. Social integration as a process to include individuals into the whole of society started out as a general term to determine the relationship between an individual and the society and the intention to ensure social cohesion (Loch, 2014); it was later adopted in the area of migration research as an opposition to an earlier concept of assimilation. 
Immigrant assimilation was first introduced in the beginning of the $20^{\text {th }}$ century, and almost completely rejected by the end of the century. Taking into account how complicated it is to separate assimilation theory from assimilationist ideology and practice, the rejection does not come as a surprise (Kivisto, 2005). Moreover, it can also be explained by the linguistic nature of the word. While in the abstract sense 'to assimilate' refers to increasing similarity or likeness, and the accent of the meaning is on the process that can happen to a varying degree, in the specific sense the meaning changes rather drastically and refers to absorption and incorporation, that is, the accent shifts to the end state and the processual and gradual component of the word disappears. It is the connotation of this particular sense, as discussed by Brubaker that has discredited the term. The notion of complete assimilation was considered "normatively retrograde" in a world that appreciates diversity, "analytically disreputable" in its understanding of the society as not much different from a biological organism and "empirically wrong" in the implication that complete absorption can be achieved. The transitive use of the verb that refers to making something similar as opposed to something becoming similar on its own volition also posed difficulties for the credibility of the term by being closely related to state programmes and policies that intended to assimilate immigrants against their will. These were not only morally objectionable but also proven to rarely have the desired effects and resulting in harsh opposition to the dominating culture on the whole (Brubaker, 2001). And while 'assimilation' has been transformed to a great extent in the past several decades and the concept of 'new assimilation' has been gaining ground in the works of immigrant research, European scholars and policy makers have remained faithful to 'integration'.

Having been adopted in immigration research as an opposition to 'assimilation', 'integration' stresses the element of immigrants' free will and diversity: the state can set measures, rules or methods, but it cannot guarantee any kind of result; moreover, a successful integration does not require the immigrant to adopt the culture of the host society (Joppke, Morawska, 2003). The definitions of the term usually tend to be rather vague, however, 'integration' could be conceptualized as a process which "includes the projection of both deep social change for the country concerned, and of fundamental continuity between the past and some idealized social endpoint" (Favell, 2010, p. 372).

While there is a vast array of different terms used to speak about the social change that needs to take place after immigration occurs (absorption, acculturation, incorporation, inclusion or accommodation to name a few), 'integration' is unmatched on two accounts. It gives coherence to a rather erratic list of policy measures aiming at construction of a well-functioning multicultural society serving as a both normative and descriptive umbrella term. It invokes a vision of an ideal state for society as a whole to be achieved and it also denotes activities carried out by the government in a way Favell refers to as "social engineering" quality of the term" (Favell, 2010). In this way, 'integration' appeals not only to academics but also to policy makers, 
and while that is useful in bringing together the relevant research and its practical application, it also possesses several issues. First, when the same vocabulary is used by scientists and politicians or journalists, it becomes difficult to differentiate between the academically charged term and a commonplace word in the public discourse; second, the scientific domain ceases to dominate the production of scientific categories and while some claims can be made in the public discourse with no significant harm, the same cannot always be applied to the scientific domain (Wieviorka, 2014). While these as well as other imperfections of the term have pushed a number of academics to refrain from its application, 'integration' still remains the most prolific sociological construct used to define a two-way process of social change that happens between the immigrant and the host society.

\section{EDUCATION AS A MEANS OF INTEGRATION}

The role of education in the process of integration can be hardly overstated. As one of the aspects of the socio-economic dimension, education provides suitable conditions for the immigrants to join the host society in terms of culture and economics. Education is fundamental in order to learn and establish cultural and behavioural patterns as well as create one's social capital and acquire skills and competences needed in the labour market (Pennix \& Garcés-Mascareñas, 2016). Schools are also the locations where the identity of the residents of a country is being formed. Education does not determine one's belonging to the society in legal or administrative terms as much as it shows and transmits an understanding about the community of a country and its boundaries, i.e., who can and cannot belong to this community (Bleich, 1999). Schools also have multiple functions when it comes to educating immigrant children: on the one hand, there is the direct function to teach; on the other, schools are also indirectly responsible for instilling cultural norms into their students. Yet, when immigrant students are concerned, schools also obtain the functions of security and control (Patel, 2013). Since the education system is not isolated and is influenced by the public discourse, certain tendencies to reproduce the fear and distrust of immigrants caused by media outlets or government security institutions can also be observed. They are usually manifested in various programmes dedicated to fight extremism either directly or indirectly (Arshad-Ayaz, Ayaz, 2017). The impact of security policy, political parties and societal attitudes are sometimes so great that it brings out the question of whether immigrant integration is indeed the goal or maybe the goal is rather to cause the impression that "something is being done" (Goodman \& Wright, 2015). As schools are the primary places that provide the immigrant children with an understanding of what kind of a society they deal with, what are its values and norms and how it is going to accept or reject them, it is of extreme importance to monitor and evaluate the effect of education to the integration of immigrant students. 


\section{RESEARCH METHODOLOGY}

The practical part of the research consisted of the analysis of Lithuanian legal documents as well as policy papers related to immigration, immigrant integration and education, meta-analysis of previous research on immigrant integration into Lithuanian society with a specific focus on education matters as well as interviews with experts. In order to gather additional data not available in written form, three semi-structured interviews with experts in the field were conducted in May, 2017. Those surveyed were the leading researchers on immigrant issues (E1), the advisor to the Minister of Science and Education of Lithuania for general education matters (E2) and the deputy director of one of the schools to which immigrant children have been enrolled (E3). The questions for these interviews were construed on the basis of already accumulated research into legal and political documents as well as the data from previous immigrant research in Lithuania. The intention of the interviews was to find out whether the reality suggested by the official documents is indeed plausible as well as to identify actual, real-world problems encountered by various subjects of the process of immigrant integration in the realm of education: students, teachers, parents, schools and their administrative bodies, the Ministry of Education of Lithuania and other governing institutions.

As this study was aimed to evaluate the possible success of the integration of immigrant children based on their education, a structural model of integration trajectories created by Christian Joppke and Ewa Morawska (2003) was employed. The model entails three different paths or trajectories of integration that an immigrant can follow: conventional, segmented or ethnic. The trajectories are distinguished based on citizenship and immigration policies employed in the receiving countries, the economic location of immigrants and their children in the host society, how racially similar they are to the members of the dominant group, how well their sociocultural capital corresponds to host life orientation and the scope and the intensity to which they are involved in various societal groups.

The first, conventional, path sees immigrants and their children integrate into the middle-class of the host society, join the mainstream economy, adopt the host cultural values and lifestyles, develop ties with the native-born members of the society and participate in political life. During this process, steady increases in host language proficiency, gradual naturalization rates as well as residential distribution (i.e., they do not create or join ghettos of the same or similar communities but rather locate themselves in different places throughout the city) among new immigrants is observed.

The second, segmented, trajectory usually applies to lower-class immigrant children who are considered as "other" by the host society based on racial or religious differences. Their social mobility towards the middle class is blocked due to discrimination from the members and institutions of the host society. This trajectory of integration refers to immigrants joining the adversary culture(s) of the lower class (in the host society) as they choose to reject mainstream sociocultural norms and values. 
The third path, ethnic (also known as bi-cultural), involves immigrants adopting the common host cultural orientations, behavioural patterns and investing themselves in the host society socially, economically and politically, while still retaining or transforming their home culture's traditions and lifestyles. Such path appears most commonly among those immigrants who move towards the middle class and remain in their ethnic niche in order to improve their socioeconomic possibilities. It is also the one chosen by those who would otherwise follow the segmented path but instead of choosing the societal norms of an adversary culture of the host society, they choose to retain their ethnic identities as a means of defence against the discrimination they face from the host society.

It is important to note that a particular immigrant or group can choose multiple integration trajectories and they all can be developed with different forms of transnational identities (Joppke \& Morawska, 2003). While neither of the paths can be described as inherently "good" or "bad", the conventional path is considered to pose the least amount of problems to both the host society and immigrants while both segmented and ethnic trajectories are more likely to result in inner or outer conflicts between immigrants and their host society.

\section{IMMIGRANT CHILDREN EDUCATION IN LITHUANIA}

Immigrant children education in Lithuania in this paper is discussed in terms of access to education, the ease of Lithuanian language acquisition, opportunities to study native language and culture, the attitudes expressed by the schools regarding the enrolment of immigrant students as well as what schools tend to be chosen by the immigrants themselves, and the level of intercultural education in the school environment.

The legislation concerning education of immigrant students can be considered quite extensive and generally favourable. The access to education is provided on the same level as it is to Lithuanian citizens, the opportunities to study Lithuanian and, to a certain extent, native languages are offered. However, there are some struggles with the practical application of this legislation, especially in terms of Lithuanian language acquisition. First, even though the students arrive from different countries, the standard amount of time that can be dedicated to Lithuanian language classes can hardly be adapted to their needs. The general requirement is $20-28$ hours per week for one school year and the funds dedicated are calculated according to this amount. This poses a practical problem, especially in the cases of recent refugee students who spend a certain amount of time in various refugee institutions before they are given refugee status and are allowed to enrol to schools. The funds are allocated only for one year and the refugee institutions provide language classes (usually by forming so called mobile groups in the schools of the region where the institution is located). However, there are cases when these classes do not ensure a satisfying result. One of the experts surveyed for this research, the deputy 
director of one of the schools to which immigrant children have been enrolled (E3), has identified this problem saying that "we had one group of students who spent all year at our school studying Lithuanian and they have managed quite well $<\ldots>$ [the other group] arrived from Rukla [the location of the refugee detention centre in Lithuania] $<\ldots>$ they had already lived in Finland for a year in a refugee camp, then they lived for half a year in Pabrade refugee camp [in Lithuania] then in Rukla and only then they arrived here $\langle\ldots\rangle$ the language problems are very grave with these children because they have spent almost two years without any kind of regular schooling experience, $<\ldots>$ they moved from one country to another, from one institution to another, maybe they even did not understand what is going on, what language they are supposed to learn and to what place they are moved time after time $\langle\ldots\rangle$ they have not learned enough Lithuanian in those two previous schools and we don't have any funds to give them additional classes" (E3). Moreover, the vast majority of Lithuanian language teachers are not qualified enough to teach Lithuanian as a foreign language as their education and work experience have been focused exclusively on teaching Lithuanian as a native language. The opportunities to study immigrants' native language, while projected in the legislation, are practically impossible since the minimum number of students to form a language group in a school is 5 with the condition that a qualified teacher is employed at the school. Given these limitations, the actual access to native language classes is possible only to immigrants arriving from the countries citizens of which comprise Lithuanian ethnic minorities (Russian or Polish).

The attitudes of Lithuanian general education schools are varying to a great extent. While some are very much willing to accept immigrant students, others express discriminating views or are somewhat reluctant to enrol such students. Both the representatives of a school (E3) and the Ministry of Education and Science (E2) pointed this out. E3 has told a story of two Muslim students who, according to the NGO worker who was helping the family, were rejected by several schools on the basis of their religion: "as soon as it was told that the children were Muslims, they would say that the school is full which makes no sense because there are very few schools which are that full $<\ldots>$ I think this is more our problem than theirs. We have some kind of negative attitude, I don't know, maybe we think that these kids will come and bomb everything here but they are absolutely fine" (E3). E2 has agreed that a certain amount of schools indeed seems to be afraid of accepting foreign students: "yes, it is a kind of reluctance, maybe even a slight fear. These students are still very much unusual to teachers and school administrators and even if they are not rejected, the communication is different $\langle\ldots\rangle$ those are not necessarily negative emotions, it's just that we lack experience" (E2). This is not surprising given that general attitudes towards immigrants in Lithuania are more negative than positive and the majority of population has not had or had very little direct contact with immigrants (Institute of Ethnic Studies, 2015). The varying attitudes can also be explained by the lack of an established immigration and integration policy. The first policy paper explicitly regarding immigrant integration - Guidelines for 
Migration Policy in Lithuania - was introduced only in 2014. To this day, there is no common strategy for immigrant integration. The most recent Strategy for Demography, Migration and Integration Policy for 2018-2030 is still in its draft stages. The proposed policy mostly focuses on solving demographic problems; both migration and integration are seen as solutions to such problems. It is difficult to say whether this may change during the later stages of introducing this strategy or implementing it upon its successful introduction. In any case, this is definitely a step in the right direction, even though, a specific strategy for immigrant integration is still very much needed. As the majority of measures provided in all legislation are mostly reactive, the schools lack institutional support that would help them be better prepared for possible immigrant students rather than "deal with them" as they arrive. The majority (about 63 per cent) of immigrant students enrol to schools where the language of instruction is Lithuanian; others choose schools with Russian or Polish as the language of instruction (Information System for Education Management). While this is not an issue in and of itself, the expert on migration matters (E1) identified a possible negative outcome: "if, say, immigrant students all automatically chose schools for ethnic minorities, their Lithuanian might not be as good, therefore, their examination results will not be as good $\langle\ldots\rangle$, they may not be able to go to study at the university, have less economic possibilities, and so on". However, the trend of enrolling to schools of ethnic minorities seems to be gradually diminishing and a growing amount of immigrant students enrol to schools with Lithuanian as the language of instruction.

The matter of intercultural education in Lithuania is a complicated one. While it is mostly considered a useful competence, it tends to be forgotten when it comes to the actual teaching and learning processes. It is not imperative to tackle these issues and whether students are introduced to the topic or not, depends almost entirely on a particular teacher. Moreover, intercultural education is oftentimes juxtaposed to ethnic education, which for various, mostly political reasons, has been gaining more ground in recent years. This results not only in lack of intercultural awareness but also in a certain cultural hierarchy whereas in the Lithuanian culture is implied as being better. A good example of such state of affairs can be found in schools located in regions where a significant amount of the residents belongs to ethnic minorities. A deputy director of such school has told the researchers that the school strongly suggested their non-Lithuanian students to use Lithuanian when talking amongst themselves during the breaks and she reminded them to do so when she heard them use their native language. It is not surprising then that such behaviour leads students of non-Lithuanian origin to be ashamed of their last names, as another informant has told (Stonkuvienè, 2015). Such extremes will probably not manifest themselves in many schools, however, they point to certain general trends that should not be overlooked. An apparent lack of intercultural competence and its teaching was also mentioned by the education expert: "we could suppose that young people, students, are culturally aware and everything is fine here but we can see many examples that Lithuanian schools do 
lack tolerance, understanding, acceptance of a different person $\langle\ldots\rangle$ and we also have teachers who don't work with these students so that they would change their attitude because they are not entirely sure how to do that" (E2). The deputy director of a school (E3) shared a more positive experience, stating that immigrant children were treated as any other new students: at first, everyone was very curious, asking them questions about their home country, their customs, later, the interest has waned; this school did not have any experience with local students being intolerant or abusive towards the newcomers.

\section{CONCLUSIONS}

While the nature of the integration process presupposes its complications and diversity, it is very difficult to determine which integration path would be chosen by immigrant children studying in Lithuanian schools. The difficulties arise for a multitude of reasons: the process of integration lacks a systematic view, a common vision; it is not cohesive and usually reactive rather than proactive.

This research has showed that the integration of a particular student mostly depends on the philosophy of a particular school and the personal motivation of its teachers who may be underprepared for working with immigrant students. Therefore, it is near impossible to decide which integration trajectory is most likely to be followed by immigrant students in Lithuania. However, the various shortcomings in legislation, negative attitudes towards immigrants and the existence of a cultural hierarchy suggest either the segmented or the ethnic path, both of which may pose significant troubles for the Lithuanian society in the future.

It is also important to note that even though the successful integration into the main society is not very likely using education as a medium, it is not as much a problem of the system of education or educators themselves as it is an outcome and a proof of other societal problems of the country.

\section{REFERENCES}

1. Arshad-Ayaz, A., \& Ayaz, N. (2017). Creating "Invited" Spaces for Counter-Radicalization and Counter-Extremism Education. Diaspora, Indigenous and Minority Education, 11(1), 6-16.

2. Bartkevičienè, A., \& Raudeliūnaitè, R. (2012). Imigrantų, atvykusių iš ne Europos Sajungos šaliu, integracijos priemoniu poreikis Lietuvoje. [The Integration Measures Needed by the Immigrants Who Arrive From Non-EU countries]. Socialinis darbas, 11(2), 341-354.

3. Bleich, E. (1999). Re-imagined Communities? Education Policies and National Belonging in Britain and France. In: A. Geddes, A. Favell (Eds..), The Politics of Belonging (pp. 60-75). Aldershot: Ashgate.

4. Brubaker, R. (2001). The return of assimilation? Changing perspectives on immigration and its sequels in France, Germany, and the United States. Ethnic and Racial Studies, 24(4), 531-548.

5. Etniniu tyrimų institutas [Institute of Ethnic Studies] (2015). Visuomenès nuostatu apklausos rezultatai (požiūris ì pabėgèlius). [Results of the public opinion survey (attitude towards refugees)]. Available at: http://www.ces.lt/wp-content/uploads/2010/02/ Po\%C5\%BEi\%C5\%ABris-\%C4\%AF-pab\%C4\%97g\%C4\%97lius-2015-m..pdf 
6. European Migration Network (2014). Asylum and Migration Glossary 3.0. European Migration Network. Available at: https://ec.europa.eu/home-affairs/sites/homeaffairs/files/whatwe-do/networks/european_migration_network/docs/emn-glossary-en-version.pdf

7. Favell, A. (2010). Integration and nations: the nation-state and research on immigrants in Western Europe. In: M. Martiniello, J. Rath (Eds.), Selected Studies in International Migration and Immigrant Incorporation (pp. 371-404). Amsterdam: Amsterdam University Press.

8. Goodman, S. W., \& Wright, M. (2015). Does Mandatory Integration Matter? Effects of Civic Requirements on Immigrant Socio-economic and Political Outcomes. Journal of Ethnic and Migration Studies, 41(12), 1885-1908.

9. Joppke, C., \& Morawska, E. (2003). Integrating Immigrants in Liberal Nation-States. In: C. Joppke, E. Morawska (Eds.), Toward Assimilation and Citizenship: Immigrants in Liberal NationStates (pp. 1-36). Basingstoke: PALGRAVE MACMILLAN.

10. Kivisto, P. (2005). The Revival of Assimilation in Historical Perspective. In: P. Kivisto (Ed.), Incorporating Diversity: Rethinking Assimilation in a Multicultural Age (p. 3-29). Boulder: Paradigm Publishers.

11. Loch, D. (2014). Integration as a sociological concept and national model for immigrants: scope and limits. Identities, 21(6), 623-632.

12. Patel, L. L. (2013). In Loco Emporium: Immigrant Youth and Educators in the Social Contracts of Education. Children \& Society, 27, 309-320.

13. Pennix, R., \& Garcés-Mascareñas, B. (2016). The Concept of Integration as an Analytical Tool and as a Policy Concept. In: R. Pennix, B. Garcés-Mascareñas (Eds.), Integration Processes and Policies in Europe (p. 11-29). Heidelberg: Springer International Publishing.

14. Platačiūtè, V., \& Žibas, K. (2014). Migrantu integracija ir migracijos tinklai Lietuvoje: nuo teorinių veiksnių iki empirinių duomenu [Migrant integration and migrant networks in Lithuania: from theoretical aspects to empirical data]. OIKOS. Lietuviu migracijos ir diasporos studijos, 2(18), 7-22.

15. Stonkuvienė, I. (2015). Cultural Identity, Language and School: the case of Lithuania. Acta Paedagogica Vilnensia, 34-48. Available at: http:// www.journals.vu.lt/acta-paedagogica-vilnensia/ article/view/8341/6213

16. Wieviorka, M. (2014). A critique of integration. Identities, 21(6), 633-641.

17. Žydžiūnaitė, V., Rupšienė, L., Kučinskienė, R., Katiliūtè, E., Saulènienė, S., Jonušaitè, S. (2005). Užsieniečių vaikų ugdymo organizavimas Lietuvos bendrojo lavinimo mokyklose [Organization of foreign children education in Lithuanian general education schools] Available at: https://www.smm.lt/uploads/documents/kiti/galutinis_koreguot_SMM_uzsienvaik_ ATASK_2006.pdf 